\title{
PREPARATION AND EVALUATION OF INSTANT NOODLES SUPPLEMENTED WITH NATURAL SOURCES OF HIGH LYSINE CONTENT
}

\author{
ABD EL-FATAH, N., AMANI A.A. METWALLI AND OMAIMA S.R. SHAMS
}

Food Tech. Res. Inst., ARC, Giza, Egypt.

(Manuscript received 4 February 2012 )

\begin{abstract}
Moringa leaf powder (MLP) and Chickpea seed powder (CSP) are good sources of protein $(30.15 \%$ and $24.5 \%$ res.), also, MLP has high crude fibre (16.2\%) and ash (12.85\%) contents which are vital for human nutrition and maintains a good health. Wheat flour (WF) has lower crude protein $(10.18 \%)$, ash $(0.63 \%)$ and crude fiber $(0.75 \%)$ contents than MLP and CSP. MLP appear to be a rich source of calcium, iron, zinc, and magnesium. CSP rich source of Zinc and magnesium, and it contains considerable amounts of iron. Whereas WF showed mineral contents lower than MLP and CSP. Beside, MLP and CSP are of high favorable amino acid balance, and considered good sources of lysine $(5.71$ and $6.89 \mathrm{~g}$ amino acid per $100 \mathrm{~g}$ protein res.). MLP and CSP proteins showed higher total amounts of essential amino acids than the FAO/WHO/UNU (1985) recommended pattern. Supplementation of wheat flour with MLP and CSP produced noodles of high protein content and improved nutritional value of noodles, particularly the content of lysine, improved its color and also to provided decorated food (greencolored noodles) to the consumer. Noodles were supplemented with MLP (at 2.5\%, 5\% and 7.5\% levels) and CSP (at 7.5\%, 10\%, $12.5 \%$ and $15 \%$ levels). Noodles were well accepted until supplementation levels 5\% MLP and $12.5 \%$ CSP to wheat flour.
\end{abstract}

\section{INTRODUCTION}

Over 143 million children under the age of five in developing countries were undernourished in 2006. Protein deficiency plays a part in the disease kwashiorkor, and lead to reduced intelligence or mental retardation. Amino acids affect the function of other nutrients in the body such as presence of lysine, which ensures adequate calcium absorption and aids in the antibodies production. (Moyo et. al., 2011).

Protein and essential amino acids which are very important for combat malnutrition problem can be found in Moringa oleifera leaves. In Africa there is the ability to grow and utilize an edible plant, Moringa commonly referred to as "The Miracle Tree". Moringa or the horseradish tree, is a pan-tropical species, it can be grown in a variety of soil conditions. It consider as one of the World's most useful trees for food, medication and industrial purposes, and improve diets and health. This 
tree was utilized by the ancient Romans, Greeks and Egyptians. Leaves are eaten as greens, in salads, vegetable curries, and as pickles. It can be eaten fresh, cooked, or stored as dried powder without refrigeration. It used as a protein supplement. Leaves are of high nutritive value, rich in vitamins, minerals with an excellent amino acid profile. It used to combat malnutrition, especially among infants and nursing mothers (Moyo et. al., 2011). Dietary consumption of its leaves is therein promoted as a strategy of personal health preservation and self-medication in various diseases, it has hypocholesterolemic, and anti-diabetic. It can protect against Alzheimer's disease and hase potent antioxidant (Das et. al., 2012).

Legumes are recognized as the best source of vegetable protein, it consider as functional ingredients for food formulation (Abou Arab et. al., 2010). Chickpea (Cicer arietinum) is one of the most important crops in the world because of its nutritional quality. In Egypt chickpea seed are usually consumed at the raw green and tender stage, called Malana, or as a popular snack food. The dry seeds can also be consumed after cooking and processing in different ways. Chickpea flour is used as a supplement in weaning food mixes, bread and biscuits. Chickpea demonstrated potentially beneficial changes to the glycaemic response, improve liver and kidney functions. It has anticancer and anti-cardiovascular diseases activities (Abou Arab et. al., 2010).

Pasta and spaghetti were fortified with chickpea. Pasta is traditional and highly popular cereal-based food product because of its convenience nutritional quality and palatability. Pasta is deficient in lysine common to most cereal products, consequently, legumes and cereals are nutritionally complementary (Abou Arab et. al., 2010).

Instant noodles is deficient in lysine common to most cereal products. Therefore, moringa leaf and chickpea seed are rich in protein, high in lysine, thus, they can be used to fortify cereals to produce a complementary food with nutritional quality. It is upon this background that this study sought to preparation and evaluation of instant noodles supplemented with moringa leaf and chickpea seed as natural sources high in lysine

\section{MATERIALS AND METHODS}

\section{Materials}

1- Wheat flour (72\%) was obtained from Milling Company, Dakahila, Egypt. 
2- Chickpea (Cicer arietinum) seeds were purchased from the local market. Seeds were ground up to pass through 100 mesh screen sieve, and the powdered samples were kept in polyethylene bags until used.

3- Moringa (Moringa oleifera) leaves were obtained from National Research Centre, Dokki, Cairo, Egypt, leaves were dried, ground up to pass through 100 mesh screen sieve, and the powdered samples were kept in polyethylene bags until used.

4- Chemicals used in this study were purchased from El-Gomhoria Company, Egypt.

\section{Methods}

\section{Analytical methods}

Moisture, crude protein, ether extract, crude fiber, ash, and Chlorophyll were determined as described in A.O.A.C. (2005). While total carbohydrates were calculated by differences.

\section{Minerals determined}

Calcium (Ca), Iron(Fe), Zinc ( $\mathrm{Zn}$ ) and magnesium (Mg) were determined according to the method described by A.O.A.C. (2005) using The perkin Elmer 3300 (USA) atomic absorption.

\section{Protein quality}

The amino acid composition was determined according to the method of Duranti and Cerletti (1979) by using amino acid analyzer (Beckman amino acid analyzer, Model $119 \mathrm{CL}$ ).Tryptophan content was determined colorimetrically, following the method of Miller (1967). Chemical score of essential amino acids were calculated using the equation of Pellet and Young (1980). PER was calculated as given by Alsmeyer et. al. (1974). Biological Value (BV) was calculated as described by Farag et. al., (1996).

\section{Noodles preparation}

Instant noodles were prepared according to Rho et. al. (1986) and Bhattacharya et. al. (1999). Different blends were prepared to obtain (7) formulas and control (100\% wheat flour). The wheat flour (72\%) was supplemented with moringa leaf powder (MLP) at $(2.5 \%, 5 \%$, and $7.5 \%)$ levels and supplemented with chickpea seed powder (CSP) at $(7.5 \%, 10 \%, 12.5 \%$ and $15 \%)$ levels. The blends were mixed well. A laboratory noodles machine was used to sheet and cut the dough. The initial sheet was formed by passing the dough through the rolls set at a gap. The final dough sheet was reduced to a final thickness of $1-5 \mathrm{~mm}$. The final dough sheet was cut by hand into $30 \mathrm{~cm}$ long sheets. These sheets where subjected to steam for ( $5 \mathrm{~min}$ ), then these samples were fried at $180^{\circ} \mathrm{C}$ for $10 \mathrm{sec}$. 


\section{Determination of cooking quality}

Noodles were put into boiled water and cooked for $3 \mathrm{~min}$, then rinsed and cooled in running cold tap water for $1 \mathrm{~min}$. Cooking loss was measured by evaporating the cooking water to dryness in oven at $100{ }^{\circ} \mathrm{C}$ as described in A.A.C.C. (2000)

\section{Sensory evaluation of cooked noodles}

Sensory evaluation of cooked noodles were evaluated for various quality attributes such as color, taste, texture and overall acceptability on a 1 to 10 hedonic scale as described by (Jayasena et. al., 2008)

Statistical analysis.

The data were statistically analyzed using the analysis of variance as out lined by Snedecor and Cochran (1980).

\section{RESULTS AND DISCUSSION}

Chemical composition of wheat flour (72\% extraction), moringa leaf powder (MLP) and Chickpea seed powder (CSP).

Data given in Table (1) represent values of crude protein, ether extract, ash, crude fiber, and total carbohydrates on dry weight basis, for wheat flour (WF), moringa leaf powder (MLP) and Chickpea seed powder (CSP). Data given in Table (1) showed that wheat flour has lower crude protein (10.18\%), ash (0.63) and crude fiber (0.75) contents than MLP and CSP. WF has high total carbohydrates (87.72\%). MLP is high in crude protein $(30.15 \%)$, crude fibre $(16.2 \%)$ and ash $(12.85 \%)$ contents. In addition to, a moderate fat content $(4.95 \%)$ and total carbohydrate $(35.85 \%)$. These results are in agreement with those reported by (Moyo et. al., 2011).

Plant food that provides more than $12 \%$ (dry basis) of its caloric value from protein is considered a good source of protein. Therefore, Moringa leaves not only meet but even more than this requirement. Moringa leaf showed relatively high crude protein making it a suitable ingredient for malnutrition diets, and making it a suitable functional ingredient for improving nutritional and organoleptic properties of food products. Moringa leaves could serve as a protein supplementary source in human diets to improve health and nutrition (Moyo et. al., 2011).

The data presented in Table (1) revealed that, chickpea (CSP) has high protein content $(24.5 \%)$ and considerable amounts of fat $(5.55 \%)$. On the other hand, it has moderat ash content (3.69\%), crude fiber (4\%) and contain high level of carbohydrate (62.26\%). Chemical composition of chickpea proved that it is an excellent protein source. These results are in agreement with those reported by (Abou Arab et. al., 2010 and Alajaji and El-Adawy, 2006). It can be concluded that MLP and CSP are excellent food material with a high nutritional value. Results which suggest that MLP and CSP could be considered good sources of protein, suitable for enriching wheat flour. 
Table 1. Chemical composition of wheat flour (72\% ext.), moringa leaf powder (MLP) and chickpea seed powder (CSP), (on dry weight basis).

\begin{tabular}{|l|c|c|c|}
\hline Component \% & Wheat flour (72\% ext.) & MLP & CSP \\
\hline Crude protein & 10.18 & 30.15 & 24.5 \\
\hline Ether extract & 00.72 & 4.95 & 5.55 \\
\hline Ash & 00.63 & 12.85 & 3.69 \\
\hline Crude fiber & 00.75 & 16.20 & 4.00 \\
\hline Total carbohydrates & 87.72 & 35.85 & 62.26 \\
\hline
\end{tabular}

Carbohydrates were calculated by difference.

Iron is required in all tissues of the body for basic cellular functions, and is critically important in muscle, brain and red blood cells. Calcium is an essential nutrient that plays a vital role in neuromuscular function, many enzyme-mediated processes, blood clotting, and providing rigidity to the skeleton. In children an extra input is needed to cover the requirements of skeletal growth (FAO/WHO, 2002). Zinc is essential for the synthesis of DNA, RNA, insulin and function and/or structure of several enzymes. Zinc is also required for cell reproduction and growth especially sperm cells. In addition, $\mathrm{Zn}$ is known for its anti-viral, antibacterial, anti-fungal and anti-cancer properties. Moringa minerals composition plays a significant role in nutritional, medicinal and therapeutic values (Moyo et. al., 2011).

Data given in Table (2) represent values of calcium (Ca), iron (Fe), zinc ( $\mathrm{Zn})$ and magnesium (Mg) for MLP, CSP and WF on dry weight basis. Data in Table (2) showed that MLP appear to be a rich source of calcium (3550 mg/100gm), iron (53 $\mathrm{mg} / 100 \mathrm{gm})$, zinc $(3.05 \mathrm{mg} / 100 \mathrm{~g})$ and magnesium $(565 \mathrm{mg} / 100 \mathrm{~g}$ ) relative to the recommended daily dietary allowances for children from 6 to 59 months of age (10 $\mathrm{mg} /$ day, $500-600 \mathrm{mg} /$ day, $4.1 \mathrm{mg} /$ day and $76 \mathrm{mg} /$ day for iron, calcium, zinc and magnesium respectively) (FAO/WHO 2002). Results are in a good agreement with that reported by (Moyo et. al., 2011). Also, CSP appear to be a rich source of Zinc (4.1 $\mathrm{mg} / 100 \mathrm{~g}$ ) and magnesium (175 mg/100g), and it contain considerable amounts of iron $(7.83 \mathrm{mg} / 100 \mathrm{gm})$, also it contain $200 \mathrm{mg} / 100 \mathrm{~g}$ calcium. Whereas WF showed mineral contents lower than MLP and CSP. Results are in a good agreement with that reported by Alajaji and El-Adawy (2006).

Data in Table (2) also showed that MLP appear to be a rich source of chlorophyll, it contain total chlorophyll $660 \mathrm{mg} / 100 \mathrm{~g}$ (on dry weight basis) 
Table 2. Minerals contents of wheat flour (72\% ext.), moringa leaf powder (MLP) and chickpea seed powder (CSP) and chlorophyll content of MLP (on dry weight basis).

\begin{tabular}{|l|c|c|c|}
\hline \multicolumn{1}{|c|}{ Minerals (mg/100g) } & Wheat flour & MLP & CSP \\
\hline $\mathrm{Ca}$ & 48.0 & 3550 & 200 \\
\hline $\mathrm{Fe}$ & 0.94 & 53.00 & 7.83 \\
\hline $\mathrm{Zn}$ & 0.72 & 3.050 & 4.1 \\
\hline $\mathrm{Mg}$ & 0.30 & 565.0 & 175 \\
\hline chlorophyll & - & 660 & - \\
\hline
\end{tabular}

Amino acid composition of wheat flour (72\%ext.) (WF), moringa leaf powder (MLP) and Chickpea seed powder (CSP).

The amino acid requirements are the logical Yard-sticks by which protein quality can be measured, and the relative quantities of the various amino acids, in particular the essential amino acids, in the food could be used as reliable estimators of actual protein quality (Alsmeyer et. al., 1974). Amino acid content of WF, MLP and CSP are shown in Table (3) along with the provisional pattern recommended by the FAO/WHO/ UNU (1985). Data presented in Table (3) clearly indicate that glutamic acid followed by alanine and aspartic acid are the most abundant amino acids of the MLP. Nevertheless, it is the essential amino acid content that count for the quality of a protein and its capacity to satisfy the needs for essential amino acids. In this concern, the tested proteins showed to have higher total amounts of essential amino acids than the FAO/WHO/UNU (1985) recommended pattern. WF showed to be relatively low in lysine content (2.15\%). Most essential amino acids in Moringa leaf is higher than those found in soybean meal. Each amino acid has a specific function in the animal's body, methionine and cystine are powerful antioxidants. Lysine is an amino acid that helps in the absorption of calcium, vitamin $C$ is essential nutritionally to make the collagen that helps the body form healthy bons, it also promotes bone healing. MLP showed to be relatively high in lysine content $(5.71 \%)$, which indicates to be superior in this concern than cereals and oil seeds. The high concentrations of methionine, cystine, tryptophan and lysine in Moringa leaves make it a virtually ideal dietary supplement. A value of $5.71 \%$ was enough to satisfy the lysine requirement as recommended by the FAO/ WHO/ UNU (1985).

It is noteworthy that moringa contains argenine and histidine. Most important is that the protein is of high quality having significant quantities of all the essential amino acids, and moringa contains all of the essential amino acids and it is rich in essential amino acids. Thus, composition of the amino acids in the leaf protein is well balanced. Our results are in agreement with (Moyo et. al., 2011) 
Data presented in Table (3) also indicate that glutamic acid was present in maximum concentration in the total amino acids content followed by aspartic acid and arginine, all essential amino acids, except S-containing types and tryptophan, are present in excessive amounts in chickpea. Chickpea considered as a good source of protein $(24.5 \%)$, rich in lysine $(6.49 \%)$. Due to its good balance of amino acid, chickpea seeds have been considered a suitable source of dietary proteins. Our results are in agreement with (Abou Arab et. al., 2010 and Alajaji and El-Adawy, 2006)

Table 3. Amino acid composition of wheat flour (72\%) (WF), moringa leaf powder (MLP) and Chickpea seed powder (CSP). (g amino acid per $100 \mathrm{~g}$ protein).

\begin{tabular}{|c|c|c|c|c|}
\hline Amino acid & WF & MLP & CSP & $\begin{array}{l}\text { FAO/WHO/ } \\
\text { UNU,1985 }\end{array}$ \\
\hline \multicolumn{5}{|c|}{ 1.Essential amino acids ( EAA ) } \\
\hline Histidine & 2.40 & 2.92 & 3.24 & 1.9 \\
\hline Isoleucine & 4.2 & 4.15 & 4.65 & 2.8 \\
\hline Leucine & 6.8 & 8.46 & 8.15 & 6.6 \\
\hline Lysine & 2.15 & 5.71 & 6.89 & 5.8 \\
\hline Methionine & 1.27 & 1.88 & 1.25 & \\
\hline Cystine & 1.4 & 1.60 & 0.72 & \\
\hline $\begin{array}{l}\text { Total sulfur amino } \\
\text { acid }\end{array}$ & 2.67 & 3.48 & 1.97 & 2.5 \\
\hline Phenylalanine & 4.60 & 5.65 & 5.69 & \\
\hline Tyrosine & 3.40 & 5.50 & 3.52 & \\
\hline $\begin{array}{l}\text { Total aromatic } \\
\text { amino acid }\end{array}$ & 8.00 & 11.15 & 9.21 & 6.3 \\
\hline Threonine & 2.90 & 4.71 & 3.72 & 3.4 \\
\hline Valine & 4.58 & 5.50 & 5.09 & 3.5 \\
\hline Tryptophan* & 1.09 & 1.68 & 1.18 & 1.1 \\
\hline Total EAA & 34.79 & 47.76 & 44.1 & 33.9 \\
\hline \multicolumn{5}{|c|}{ 2.Non- essential amino acids ( N EAA ) } \\
\hline Alanine & 4.03 & 10.08 & 4.42 & \\
\hline Arginine & 7.34 & 6.96 & 9.05 & \\
\hline Aspartic acid & 9.10 & 8.96 & 11.3 & \\
\hline Glutamic acid & 24.09 & 10.98 & 17.8 & \\
\hline Glycine & 4.35 & 5.56 & 4.08 & \\
\hline Proline & 11.5 & 5.53 & 4.55 & \\
\hline Serine & 4.80 & 4.17 & 4.7 & \\
\hline Total NEAA & 65.21 & 52.24 & 55.9 & \\
\hline
\end{tabular}

* Tryptophan was determined colorimetrically.

\section{The chemical score:}

The chemical score of WF, MLP and CSP are listed in Table (4), along with the amino acid score pattern for the FAO/WHO/UNU(1985). 
Amino acid score is very important to evaluate the content of essential amino acids in foods and also to be enough the nutritional requirements of protein. WF is deficient in lysine and has low chemical score of being 37.06. Leaves of moringa are rich in protein $(30.15 \%)$ and contain considerable amounts of essential amino acids (47.76\%). Lysine has high chemical score of being 98.5. The values of amino acids profile reflect a desirable nutritional balance (Moyo et. al., 2011).

Table 4. Essential amino acids (mg/kg protein) of wheat flour (72\%) (WF), moringa leaf powder (MLP) and Chickpea seed powder (CSP) proteins and their chemical scores in respect to FAO/WHO/UNU, 1985

\begin{tabular}{|c|c|c|c|c|c|c|c|}
\hline \multirow[t]{2}{*}{ (EAA) } & \multirow{2}{*}{$\begin{array}{l}\text { FAO/WHO } \\
\text { /UNU,1985 }\end{array}$} & \multicolumn{2}{|c|}{ WF } & \multicolumn{2}{|c|}{ MLP } & \multicolumn{2}{|r|}{ CSP } \\
\hline & & $\begin{array}{l}\mathrm{mg} / \mathrm{kg} \\
\text { protein }\end{array}$ & CS & $\begin{array}{l}\mathrm{mg} / \mathrm{kg} \\
\text { protein }\end{array}$ & CS & $\begin{array}{l}\mathrm{mg} / \mathrm{kg} \\
\text { protein }\end{array}$ & CS \\
\hline Histidine & 19 & 24.0 & 126.3 & 29.2 & 153.7 & 32.4 & 170.53 \\
\hline Isoleucine & 28 & 42.0 & 150 & 41.5 & 148.2 & 46.5 & 166.07 \\
\hline Leucine & 66 & 68.0 & 103 & 84.6 & 128.18 & 81.5 & 123.49 \\
\hline Lysine & 58 & 21.5 & $37.06 *$ & 57.1 & 98.5 & 68.9 & 118.79 \\
\hline Methionine & & 12.7 & & 18.8 & & 12.5 & \\
\hline Cystine & & 14.0 & & 16.0 & & 7.2 & \\
\hline $\begin{array}{l}\text { Total sulfur } \\
\text { amino acid }\end{array}$ & 25 & 26.7 & 106.8 & 34.8 & 139.2 & 19.7 & 78.8* \\
\hline Phenylalanine & & 46.0 & & 56.5 & & 56.9 & \\
\hline Tyrosine & & 34.0 & & 55.0 & & 35.2 & \\
\hline $\begin{array}{l}\text { Total aromatic } \\
\text { amino acid }\end{array}$ & 63 & 80.0 & 126.9 & 111.5 & 176.98 & 92.1 & 146.19 \\
\hline Threonine & 34 & 29.0 & 85.29 & 47.1 & 138.5 & 37.2 & 109.41 \\
\hline Valine & 35 & 45.8 & 130.85 & 55.0 & 157.1 & 50.9 & 145.43 \\
\hline Tryptophan & 11 & 10.9 & 99 & 16.8 & 152.7 & 11.8 & 107.27 \\
\hline
\end{tabular}

$*$ limiting amino acid

EAA = Essential amino acids

$\mathrm{CS}=$ chemical score

Data from Table (4) show that CSP protein, like some other legumes, are common deficient in sulfur-containing amino acids, which are the limiting amino acids. These deficiencies need to be considered when CSP are used for nutrition purposes, however, lysine has high chemical score of being 118.79. Amino acid profile showed methionine and cystine as the limiting amino acids (78.8). Tryptophan was not observed to be the limiting amino acid in chickpea (107.27). Results are comparable to those of earlier workers (Abou Arab et. al., 2010). Amino acid deficiency can be 
met by employing the complementarity that exists between high sulphur amino acid cereals and legumes.

\section{Protein efficiency ratio and biological value}

The most widely used method for the measurement of protein quality is the protein efficiency ratio (PER) (Alsmeyer et. al., 1974 ). The values of PER and biological values (BV) of wheat flour (72\%) (WF), moringa leaf powder (MLP) and chickpea seed powder (CSP) proteins are presented in Table (5). The PER and BV of WF, MLP and CSP proteins were found to be 2.26, 2.79, 2.86 and 73.69, 79.28, 80.02, respectively. MLP and CSP proteins showed to have PER value and BV higher than, that of casein, indicating that the MLP and CSP proteins are of high nutritional value. our results are in agreement with (Thurber and Fahey, 2009) who reported that, moringa leaves are high in protein quality, and its protein quality rivals that of milk.

The inclusion of pulses in cereal based food is known to increase the nutritive value by improving protein content, particularly the content of lysine (Abou Arab et. al., 2010). In general, it could be concluded that MLP and CSP are of high favorable amino acid balance, and considered a good source of lysine, and is worthy to be incorporated into cereal products such as noodles. Supplementation of wheat flour with MLP and CSP could produce noodles of high protein content and improve nutritional value of this noodles, particularly the content of lysine.

Table 5. Protein efficiency ratio (PER) and biological value (BV) of wheat flour (72\%) (WF), moringa leaf powder (MLP) and Chickpea seed powder (CSP) proteins.

\begin{tabular}{|c|c|c|}
\hline Sample & PER & BV \\
\hline WF & 2.26 & 73.69 \\
\hline MLP & 2.79 & 79.28 \\
\hline CSP & 2.86 & 80.02 \\
\hline Casein(reference) & 2.50 & 76.23 \\
\hline
\end{tabular}

\section{Chemical composition of produced noodles}

Data given in Table (6) represent values of protein, ether extract, ash, crude fiber and total carbohydrates on dry weight basis, for supplemented noodles with MLP (at $2.5 \%, 5 \%$ and $7.5 \%$ level) and CSP (at 7.5\%, 10\%, 12.5\% and $15 \%$ level) as well as control (100\% wheat flour) after cooking. Data showed that supplement of wheat flour with $2.5 \%, 5 \%$ and $7.5 \%$ of MLP as well as supplement of wheat flour with $7.5 \%, 10 \%, 12.5 \%$ and $15 \%$ of CSP showed increase in protein, fat, ash and crude fiber contents while carbohydrate contents were decreased for all supplementation levels. MLP-supplemented noodles showed increase in ash and crude fiber contents, with highest value for the $7.5 \%$ supplement relative to the control noodles, this might be due to the high ash and crude fiber contents of MLP than that of wheat flour. Also, 
protein increased of its blends compared to the control noodles at all levels of supplement. Data showed slightly increase in fat content. Changes in chemical composition was proportional to the level of supplement. These results are in agreement with those reported by (Dachana et. al., 2010)

Data in Table (6) also showed that, supplement of wheat flour with $7.5 \%$, $10 \%, 12.5 \%$ and $15 \%$ of CSP showed increase in protein, fat, ash and crude fiber contents in noodles samples compared to the control noodles and the maximum content of protein in samples present in noodles contained chickpea was $12.35 \%$ at replacement level $15 \%$. On the other hand, carbohydrate contents were decreased for all supplementation levels, and the changes, positively or negatively, were proportional with the level of addition, our results are in agreement with those reported by (Abou Arab et. al., 2010)

Table (6) showed also the composition of elements: Calcium ( $\mathrm{Ca})$, iron ( $\mathrm{Fe}$ ), zinc ( $\mathrm{Zn}$ ) and magnesium (Mg) for supplemented noodles with MLP (at 2.5\%, 5\% and $7.5 \%$ levels), CSP (at 7.5\%, 10\%, 12.5\% and 15\% levels) and control (100\% WF) after cooking, on dry weight basis. Data in Table (6) showed that supplement of wheat flour with MLP and CSP showed increase in $\mathrm{Ca}, \mathrm{Fe}, \mathrm{Zn}$ and $\mathrm{Mg}$ contents at all supplementation levels, with highest value for MLP at 7.5\% level and for CSP at $15 \%$ level supplement relative to the control noodles. This might be due to the high mineral contents of MLP and CSP than that of wheat flour. These results are in agreement with those reported by (Abou Arab et. al., 2010 and Dachana et. al., 2010)

From the previous results it should be conclude that, nutrients such as vegetable protein from MLP and CSP have high nutritional value and should be included as part of an intervention diet. 
Table 6. Chemical composition and minerals contents of the supplemented noodles with moringa leaf powder (MLP) and chickpea seed powder (CSP) at different levels (on dry weight basis).

\begin{tabular}{|c|c|c|c|c|c|c|c|c|}
\hline & Control & $\begin{array}{l}\text { MLP } \\
2.5 \%\end{array}$ & MLP 5\% & $\begin{array}{l}\text { MLP } \\
7.5 \%\end{array}$ & $\begin{array}{l}\text { CSP } \\
7.5 \%\end{array}$ & $\begin{array}{l}\text { CSP } \\
10 \%\end{array}$ & $\begin{array}{l}\text { CSP } \\
12.5 \%\end{array}$ & $\begin{array}{l}\text { CSP } \\
15 \%\end{array}$ \\
\hline Crude protein & 10.14 & 10.71 & 11.2 & 11.7 & 11.29 & 11.65 & 12.0 & 12.35 \\
\hline Ether extract & 12.00 & 12.11 & 12.21 & 12.32 & 12.36 & 12.48 & 12.61 & 12.73 \\
\hline Ash & 1.00 & 1.31 & 1.61 & 1.92 & 1.24 & 1.32 & 1.40 & 1.48 \\
\hline Crude fiber & 1.15 & 1.60 & 2.01 & 2.40 & 1.38 & 1.49 & 1.58 & 1.69 \\
\hline $\begin{array}{c}\text { Total } \\
\text { carbohydrates }\end{array}$ & 75.71 & 74.27 & 72.97 & 71.66 & 73.73 & 73.06 & 72.41 & 71.75 \\
\hline \multicolumn{9}{|c|}{ Minerals (mg/100g) } \\
\hline $\mathrm{Ca}$ & 53.0 & 140.54 & 228.08 & 315.66 & 64.5 & 68.19 & 72.05 & 75.79 \\
\hline $\mathrm{Fe}$ & 1.35 & 2.66 & 3.95 & 5.26 & 1.88 & 2.04 & 2.22 & 2.39 \\
\hline $\mathrm{Zn}$ & 0.80 & 0.86 & 0.92 & 0.98 & 1.06 & 1.14 & 1.23 & 1.32 \\
\hline $\mathrm{Mg}$ & 0.34 & 14.46 & 28.58 & 42.69 & 13.44 & 17.8 & 22.18 & 26.56 \\
\hline
\end{tabular}

\section{Cooking quality of produced noodles}

Data given in Table (7) represent values of increasing weight, weight gain percentage and uncooked to cooked weight $(\mathrm{g})$ ratio after cooking the supplemented noodles with MLP and CSP at different levels. Table (7) showed increase in cooked weight and weight gain percentage for all supplementation levels relative to control noodles, while showed decrease in uncooked to cooked weight ratio for all supplementation levels relative to control noodles. Changes in cooked weight, weight gain percentage and uncooked to cooked weight ratio was proportional to the level of supplement. These results indicated that the control noodles had the lowest cooked weight and weight gain percentage value comparing with the other noodles. The overall network that holds noodle structure may consist primarily of protein and starch matrices. These matrices gradually disintegrate during cooking that results in the absorption of water followed by swelling up of starch granules and increasing weight. A number of factors such as hydrophilic-hydrophobic balance of amino acids molecular size and shape influence the water absorption of flours. An oil absorption capacity is due to binding of fat by non-polar side chains of proteins. These results might be due to that moringa leaf powder and chickpea seed powder have high fiber and protein contents, water holding capacity and oil holding capacity comparing with wheat flour, which affect of water and oil adsorption and, consequently, increasing weight. Our results are in agreement with (Dachana et. al., 2010) who reported that, incorporation 
of increasing amount of moringa increased farinograph water absorption. Flours with high water absorption have more hydrophilic constituents, such as polysaccharides. Therefore, the higher water absorption capacity of CSP than WF could be attributed to the presence of greater amounts of hydrophilic constituents in them. The inherent proteins in CSP may also have played some role in the higher water absorption capacity. On the other hand, oil absorption capacity of CSP was high because it had more available non-polar side chains in its protein molecules (Abou Arab et. al., 2010 and Alajaji and El-Adawy, 2006)

Table 7. Increasing weight and uncooked to cooked weight $(\mathrm{g})$ ratio after cooking the supplemented noodles with moringa leaf powder (MLP) and chickpea seed powder (CSP) at different levels.

\begin{tabular}{|c|c|c|c|c|}
\hline & Sample weight & \multicolumn{3}{|c|}{ Weight ratio after 3 min } \\
\cline { 2 - 5 } & $(\mathrm{g})$ & Weight $(\mathrm{g})$ & Percentage & Ratio \\
\hline Control & 10 & 22.25 & $122.5 \%$ & 0.449 \\
\hline MLP 2.5\% & 10 & 24.35 & $143.46 \%$ & 0.411 \\
\hline MLP 5.0\% & 10 & 24.72 & $147.17 \%$ & 0.405 \\
\hline MLP 7.5\% & 10 & 25.39 & $153.88 \%$ & 0.394 \\
\hline CSP 7.50\% & 10 & 22.65 & $126.5 \%$ & 0.442 \\
\hline CSP 10.0\% & 10 & 25.16 & $151.6 \%$ & 0.398 \\
\hline CSP 12.5\% & 10 & 27.82 & $178.2 \%$ & 0.360 \\
\hline CSP 15.0\% & 10 & 30.49 & $204.9 \%$ & 0.328 \\
\hline
\end{tabular}

Control $=100 \%$ Wheat flour

Cooking loss is one of the most important factors that influence the cooking quality of the noodles, high cooking loss is undersirable, since it represents high solubility of starch, resulting turbid cooking water, low cooking tolerance and sticky mouthfeel. Table (8) illustrated the changes in the cooking loss as a function of supplemented noodles with MLP and CSP at different levels. Data in Table (8) showed that supplement of wheat flour with MLP and CSP showed decrease in cooking loss relative to the control noodles at all supplementation levels. The control noodles had the highest cooking loss value comparing with the other noodles. These results might be due to a number of factors such as starch granules, solubility of starch, high fiber and protein contents of MLP and CSP. A possible reason for these results is that gelatinized starch can prevent leaching of soluble material into water. 
Table 8. Cooking loss of the supplemented noodles with moringa leaf powder (MLP) and chickpea seed powder (CSP) at different levels (on dry weight basis).

\begin{tabular}{|c|c|c|}
\hline & Sample weight $(\mathrm{g})$ & Cooking loss $\%$ after 3 min \\
\hline Control & 10 & $8.23 \%$ \\
\hline MLP 2.5\% & 10 & $7.67 \%$ \\
\hline MLP 5.0\% & 10 & $7.35 \%$ \\
\hline MLP 7.5\% & 10 & $7.15 \%$ \\
\hline CSP 7.50\% & 10 & $6.14 \%$ \\
\hline CSP $10.0 \%$ & 10 & $5.95 \%$ \\
\hline CSP $12.5 \%$ & 10 & $5.35 \%$ \\
\hline CSP $15.0 \%$ & 10 & $5.02 \%$ \\
\hline
\end{tabular}

\section{The organoleptic characteristics of produced noodles}

The organoleptic characteristics of noodles prepared from wheat flour as control and of the noodles prepared from wheat flour containing different levels of moringa leaf powder (MLP) and chickpea seed powder (CSP) are given in Table (9). From data presented in Table (9) it could be observed that supplementation of noodles with MLP led to significant increase the color at $5 \%$ and $7.5 \%$ supplementation levels relative to control noodles, while texture significant increase at all supplementation levels relative to control noodles. The taste significant increase at $5 \%$ substitution with MLP while no significant difference at $2.5 \%$ and $7.5 \%$ supplementation levels relative to control. The noodles were accepted until supplementation level $7.5 \%$ MLP to wheat flour, while they were well accepted at supplementation level 5\% MLP. MLP improve the overall appearance of noodles, and also contribute to consumers' health and well-being (Thurber and Fahey, 2009, Dachana et. al., 2010 and Das et. al., 2012)

Supplementation of noodles with CSP led to significant increase the taste and texture at all supplementation levels relative to control noodles, while color significant increase at $10 \%, 12.5 \%$ and $15 \%$ supplementation levels relative to control noodles. The noodles were accepted until supplementation level $15 \%$ CSP to wheat flour, while they were well accepted at supplementation level $12.5 \%$ CSP. This would definitely encourage the utilization of MLP and CSP to be incorporated in noodles to improve its color and nutritional value and also to provide decorated food (green-colored noodles with MLP) to the consumer. These results are in agreement with that found by (Johnson et. al., 2005). 
Table 9. Organoleptic characteristic of the supplemented noodles with moringa leaf powder (MLP) and chickpea seed powder (CSP) at different levels.

\begin{tabular}{|l|c|c|c|c|}
\hline & Color & Taste & Texture & Overall \\
& $(10)$ & $(10)$ & $(10)$ & Acceptability \\
\hline Control & $8.5^{\mathrm{a}}$ & $8.5^{\mathrm{a}}$ & $8.0^{\mathrm{a}}$ & $25^{\mathrm{a}}$ \\
\hline MLP 2.5\% & $8.5^{\mathrm{a}}$ & $8.5^{\mathrm{a}}$ & $8.5^{\mathrm{b}}$ & $25.5^{\mathrm{b}}$ \\
\hline MLP 5\% & $8.9^{\mathrm{d}}$ & $9.0^{\mathrm{d}}$ & $9.0^{\mathrm{c}}$ & $26.9^{\mathrm{cd}}$ \\
\hline MLP 7.5\% & $9.2^{\mathrm{d}}$ & $8.5^{\mathrm{a}}$ & $9.0^{\mathrm{c}}$ & $26.7^{\mathrm{c}}$ \\
\hline CSP 7.5\% & $8.3^{\mathrm{c}}$ & $8.7^{\mathrm{b}}$ & $8.5^{\mathrm{b}}$ & $25.5^{\mathrm{b}}$ \\
\hline CSP 10\% & $8.8^{\mathrm{b}}$ & $9.0^{\mathrm{d}}$ & $9.0^{\mathrm{c}}$ & $26.8^{\mathrm{cd}}$ \\
\hline CSP 12.5\% & $9.0^{\mathrm{d}}$ & $9.2^{\mathrm{d}}$ & $9.3^{\mathrm{cd}}$ & $27.5^{\mathrm{d}}$ \\
\hline CSP 15\% & $8.9^{\mathrm{d}}$ & $9.1^{\mathrm{d}}$ & $9.25^{\mathrm{cd}}$ & $27.25^{\mathrm{d}}$ \\
\hline
\end{tabular}

Values followed by the same letter in same column are not significantly different at $p \leq 0.05$ Control $=100 \%$ Wheat flour

\section{CONCLUSION}

Reviewing above mentioned results obtained in this study, it could be concluded that MLP and CSP are good sources of protein, crude fiber, and minerals (calcium, iron, zinc, and magnesium) which are vital for human nutrition and maintains a good health, beside, MLP and CSP are of high favorable amino acid balance, and considered a good source of lysine, and is worthy to be incorporated into cereal products such as noodles. Supplementation of wheat flour with MLP and CSP produce noodles of high protein content and improve nutritional value of this noodles, particularly the content of lysine. Noodles were well accepted until supplementation levels 5\% MLP and $12.5 \%$ CSP to wheat flour. 


\section{REFERENCES}

1. A.A.C.C. 2000. American Association of Cereal Chemists. Approved Methods of The AACC,10th ed. Method 1015 D, The Association St. Paul MN.

2. Abou Arab, E.A., I.M.F. Helmy and G.F. Bareh 2010. Nutritional Evaluation and Functional Properties of Chickpea (Cicer arietinum L.) Flour and the Improvement of Spaghetti Produced from its. Journal of American Science Vol. 6(10):10551072

3. Alajaji, A.S. and A.T. El-Adawy 2006. Nutritional composition of chickpea (Cicer arietinum L.) as affected by microwave cooking and other traditional cooking methods. J. of Food Composition and Analysis 19, 806-812.

4. Alsmeyer, R.H., A.E. Cunningham and M.L. Happich (1974). Equations predict PER from amino acid analysis. Food Technol., 28 (7): 34- 40

5. A.O.A.C. 2005. Official Methods of Analysis of the Association of Official Analytical Chemists. Washington D.C. USA.

6. Bhattacharya M., S.Y. Zee and H. Corke 1999. Physicochemical properties related to quality of rice noodles. Cereal chem 76: 866-867

7. Dachana, K.B., J. Rajiv, D. Indrani and J. Prakash 2010. Effect Of Dried Moringa (Moringa Oleifera Lam) Leaves On Rheological, Microstructural, Nutritional, Textural And Organoleptic Characteristics Of Cookies. Journal of Food Quality, 33(5): 660-677

8. Das, A.K., V. Rajkumar, A.K. Verma and D. Swarup 2012, Moringa oleiferia leaves extract: a natural antioxidant for retarding lipid peroxidation in cooked goat meat patties. International Journal of Food Science and Technology, 47(3): 585-591

9. Duranti, M. and P. Cerletti 1979. Amino acid composition of seed products of Lupinus albus. J. Agric. Food Chem., 27:977-978.

10. FAO/ WHO/ UNU Expert Consultation 1985. Energy and protein requirements.Technical report series 724.World Health Organization, Geneva.

11. FAO/WHO. 2002. Human vitamin and mineral requirements. Report of a joint FAO/WHO expert consultation. Bangkok, Thailand

12. Farag, S.A. , A. El-Shirbeeny and E.N. Ashgan 1996. Physicochemical studies for preparing quick-cooking rice by using gamma irradiation. Annals of Agric. Sci., Moshtohor, 34: 641-652.

13. Jayasena,V., P. Leung and S.M. Nasar-Abbas 2008. Lupins for health and wealth proceedings of the 12th International Lupin Conference, 14-18 Sept. 2008, Fremantle, Western Australia. International Lupin Association, Canterbury, New Zealand. ISBN 0-86476-153-8. 
14. Johnson, S.K., S.J. Thomas and R.S. Hall 2005. Palatability and glucose, insulin and satiety responses of chickpea flour and extruded chickpea flour bread eaten as part of a breakfast. European Journal of Clinical Nutrition. 59, 169-176

15. Miller, E.L. 1967. Determination of the tryptophan content of feeding stuffs with particular reference to cereals. J. Sci. food Agric., 18: 381-387

16. Moyo, B., P.J. Masika, A. Hugo and V. Muchenje 2011. Nutritional characterization of Moringa (Moringa oleifera Lam.) leaves. African Journal of Biotechnology Vol. 10(60): 12925-12933

17. Pellet, P.L. and V.R. Young 1980. Nutritional evaluation of food proteins. Food and Nutritional Bulletin Supplement 4. The United Nations University, Tokyo, Japan.

18. Rho, K.I., O.K. Chung and D.S. Chung 1986. Retardation of rancidity in deepfried noodles (Ramyon). J. A. O. C. S 63(2): 251-256

19. Sendecor, G.W. and W.C. Cochran 1980. Statistical Methods Oxford and J.B.H. Publishing Com. 7th ed.

20. Thurber, M.D. and J.W. Fahey 2009. Adoption of Moringa oleifera to combat under-nutrition viewed through the lens of the "Diffusion of Innovations" theory. Ecol Food Nutr. 48(3): 212-225 
تجهيز و تقييم نودلز ملونة و مدعمة بمصادر طبيعية عالية محتوى الليسين

نبيل عبد الفتاح امانى عبد الرحمن على متولى اميمة شمس

$$
\text { معهُ بحوث وتكنولوجيا الأغذية - مركز البحوث الزراعبة - جيزة }
$$

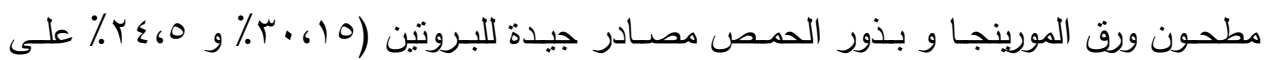

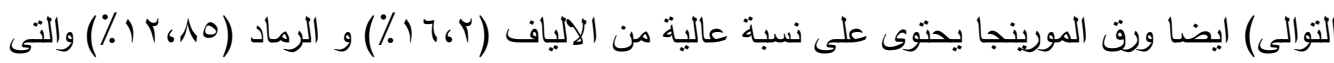
تعتبر حيوية و هامة فى تغذية الانسان و الحفاظ على صحته. دقيق القمح يحتوى على بروتين و رماد

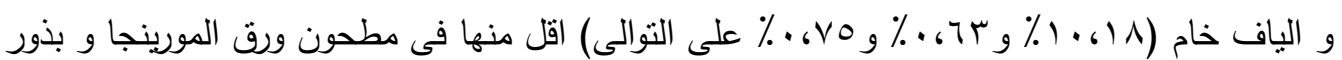

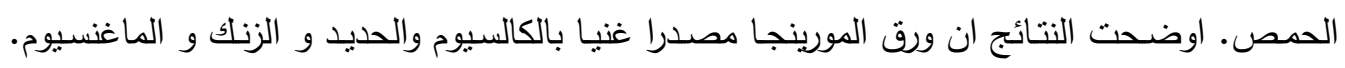

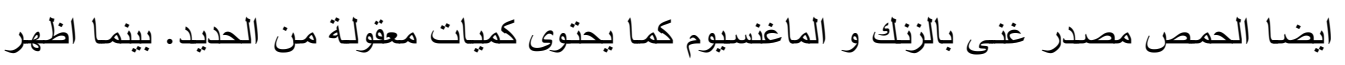
دقيق القمح محتوى اقل من المعادن مقارنة بكل من المورينجا و الحمص. بجانب محتوى المورينجا و

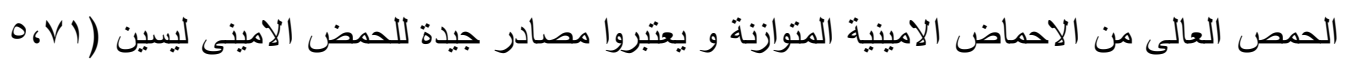

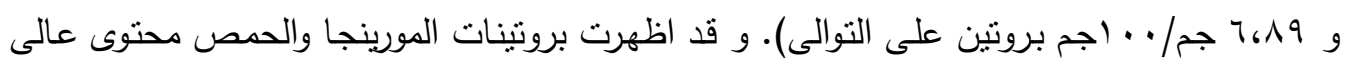

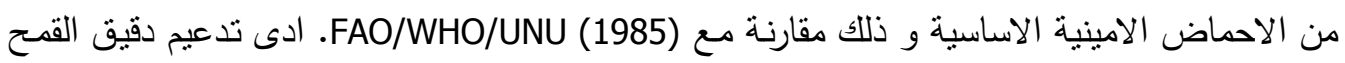

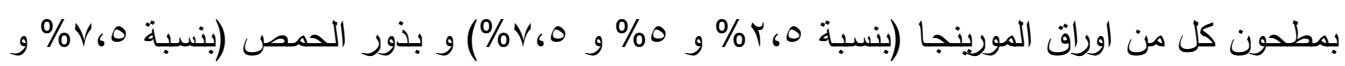

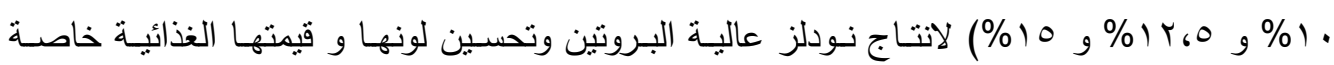

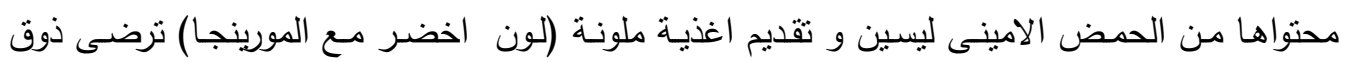

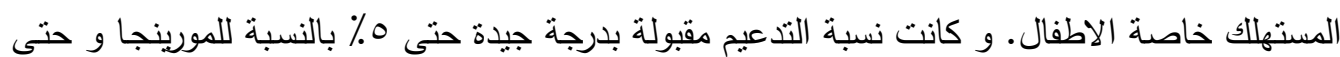
0، Y \% بالنسبة للحمص. 